\title{
CARVALHO, Bernardo. O sol se põe em São Paulo. São Paulo: Companhia das Letras, 2007.
}

\author{
Marcílio França Castro \\ Universidade Federal de Minas Gerais
}

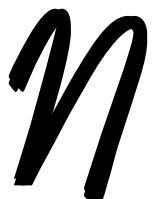

ão por acaso, tal como em seus dois romances anteriores, Nove noites (2002) e Mongólia (2003), também em O sol se põe em São Paulo, de 2007, Bernardo Carvalho elege como narrador a figura de um escritor fracassado. "O melhor escritor é o que nunca escreveu nada" - esta é a frase que, como uma chave profética, ecoa por toda a narrativa, proferida por uma velha imigrante japonesa, dona de um restaurante em São Paulo, e repetida pelo homem contratado para transformar a história dela em romance, um redator desempregado e sem família, bisneto de imigrantes japoneses, cujo projeto de tornar-se escritor nunca se concretizou. A ideia de um escritor sem livros, mas sempre na iminência de escrever, parece ser a condição desse projeto literário que, reiterado na obra de Carvalho, solicita uma espécie contemporânea de escriba, desprovido de lembranças pessoais e da experiência do testemunho, mas disposto a ouvir e relatar as histórias dos outros, e a imaginar aquilo que ignora. Afinal, "a literatura é o que não se vê"

Em O sol se põe em São Paulo, os acontecimentos não foram vividos por quem os narra, a memória que se transmite é a alheia, a única experiência acessível é a do outro. O eu, essa entidade provisória, descartável e quase sem afeto, preocupado a princípio em registrar e comunicar, seria apenas aquele que 
enuncia a frase. Entretanto, paradoxalmente, sobrevivendo no vazio, esse eu de aluguel é o que mantém a máquina narrativa em movimento e a converte em romance. "Só é possível narrar as histórias do outro": a fórmula, também esta repetida na boca de mais de um personagem, e com similar em outros romances do autor, como Mongólia ("a literatura quem faz são os outros"), constitui talvez a premissa mais importante do romance e responde à epígrafe do livro, uma citação de Paul Valery, na qual se evocam "os estranhos discursos, que parecem feitos por um personagem distinto daquele que os diz e dirigir-se a outro, distinto daquele que os escuta".

A tarefa que se anuncia para quem escreve, dessa maneira, não é apenas a de reproduzir uma história já pronta, como um intermediário passivo; seu papel é, antes, o de descobrir que história está sendo contada, costurar os fios de relatos despedaçados e enganosos, que se desdobram em outros relatos, entre nomes falsos, embustes e papéis trocados. Contando com a colaboração do acaso, esse narrador (que, em O sol se põe em São Paulo, é o único personagem sem nome) deve ser capaz, como um copista, de ouvir e de registrar; como um pesquisador, de investigar as pistas; como um compilador, de organizar as peças; como um escritor, de tornar a narrativa plausível e transmiti-la aos outros. Afinal, "um escritor só pode ser enquanto não for".

O sol se põe em São Paulo é um vertiginoso quebra-cabeças, com um enredo difícil de resumir; a tentativa de montar suas peças e dar-lhes sentido constitui o próprio romance. Os dezoito capítulos que integram o livro poderiam ser divididos em duas partes distintas. Na primeira, até o capítulo 8, o narrador reproduz a história que lhe conta Setsuko, a dona do restaurante, em uma linguagem contaminada pelo "estilo respingado" que ele atribui à fala da mulher. No Japão da Segunda Guerra, uma espécie de triângulo amoroso envolve Masukichi, um enigmático e sedutor ator de kiogen, o teatro 
cômico japonês, Michiyo, a filha de uma tradicional e decadente família nipônica, apaixonada pelo ator, e um filho de ricos industriais de hábitos ocidentais, Jokichi, com quem a jovem se casa. A contratação, pelo pai de Jokichi, de um pobre camponês para lutar na guerra no lugar do filho, e assim livrá-lo da morte certa no campo de batalha, é o fato que está no centro das interrogações e arrasta a intriga até o final. Na segunda parte, a partir do capítulo 9, a dona do restaurante desaparece sem dar explicação, e o narrador se vê impelido a viajar ao Japão na tentativa de dar continuidade à história que sua interlocutora tinha deixado interrompida. Uma carta escrita por ela ao ator de kiogen, da qual casualmente o narrador acaba se apossando, fará uma série de revelações e conduzirá o narrador de volta ao Brasil, onde, em Promissão, no interior de São Paulo, o mirabolante quebra-cabeças se completa, ao entrar na história um primo do imperador japonês na época da guerra.

O teatro kyogen pode ser tomado como uma metáfora contínua da narrativa, que à semelhança de seus atos se desenvolve. Kiogen quer dizer "farsa, artimanha, simulação". Como no teatro, tudo no romance é artifício: não apenas os nomes e os acontecimentos, mas também os bosques e os livros, as cidades e a arquitetura, como a fachada do sobrado onde fica o restaurante japonês, em São Paulo, e a própria cidade, que, segundo o narrador, "quer passar pelo que não é". Os personagens, como atores, parecem encenar cada um de seus movimentos; não têm consistência moral ou psicológica, não se colam a nenhuma identidade, nem mesmo a constroem ao longo do discurso. São vozes flutuantes, cuja existência é reconhecida apenas pela máscara utilizada a cada cena (aqui a evocação de Confissões de uma máscara, de Mishima). "O ator de kyogen deve agir na vida como se atuasse num teatro kyogen", esse é o conselho que o ator Masukichi dá a Michiyo. De certa maneira, o romance parece abdicar da pretensão realista de esconder as marcas da ficção; ao contrário, a ideia de literatura 
como simulação é a todo tempo reafirmada. Nesse universo em que apenas as máscaras falam, nenhum discurso traz marca pessoal, a única subjetividade possível parece ser a da própria escrita, uma subjetividade precária e evasiva, construída na tentativa desesperada do narrador de sobreviver por meio do próprio ato de narrar.

A incorporação de figuras históricas como personagens, embora a princípio possa sugerir uma perturbação no estatuto ficcional da narrativa, talvez acabe colaborando para acentuar $o$ efeito de simulação presente no romance. A trama que envolve as personagens toca a biografia dos escritores Mishima e Junichiro Tanizaki e os atrai para dentro da história. No caso de Tanizaki, uma série de coincidências biográficas, apontadas pelo próprio narrador (a morada nos arredores de um templo, a publicação interrompida de um romance, a mão paralisada), aproxima o autor de Elogio da sombra da personagem do velho romancista que dita histórias para Michiyo, aqui no papel de copista, registrar. O jogo entre ficção e realidade torna-se objeto do romance.

Essas relações tornam-se ainda mais complexas na medida em que os textos de algumas crônicas assinadas por Bernardo Carvalho e publicadas em jornal confundem-se com certas passagens do romance. É o caso da crônica "Estranhos num trem", publicada originalmente em dezembro de 2004 na Folha de S. Paulo e depois incluída no livro O mundo fora dos eixos, de 2005. A crônica narra um encontro casual, num trem de Tóquio para Kyoto, entre Carvalho e uma senhora japonesa e o jantar insólito para o qual ele é convidado na casa da mulher e de seu marido. $\mathrm{O}$ texto da crônica aparece reaproveitado nos capítulos 15 e 16 do romance, nos quais o narrador, indo de Osaka para Tóquio, encontra uma mulher, e depois recebe um fax do marido (que, como na crônica, é um professor universitário e tem lábio leporino) também com um convite para o jantar. No 
texto do jornal, o cronista escapa em pânico do apartamento; no do romance, o professor vai traduzir para o narrador a carta que esclarece os mistérios da narrativa de Michiyo.

Temos aqui um duplo movimento. Por um lado, esse tipo de narrativa híbrida, que incorpora explicitamente traços históricos ou biográficos, reforça a expectativa, por parte do público leitor, de um romance baseado em "fatos reais" e abre espaço, em maior ou menor grau, para uma recepção do livro como romance que contém elementos autobiográficos, ainda que de forma enganosa, muitas vezes atendendo aos interesses do mercado editorial. Por outro lado, é a própria narrativa que vai desestabilizar a crença ingênua que ela mesma provoca, ao pôr definitivamente em xeque a veracidade das referências e dos fatos que menciona. O que passa a ser interrogado aqui é o próprio campo da chamada realidade e o dos discursos que se anunciam como presos a ela.

Os artifícios utilizados por Carvalho em O sol se põe em São Paulo nos remetem inevitavelmente a Jorge Luis Borges, que aparece citado pelo narrador logo no início do romance. Os nomes falsos, a inversão de papéis, os embustes biográficos e históricos, a evocação dos livros, o traço erudito, a forma detetivesca, todas essas manobras aproximam a literatura de Carvalho dos relatos borgeanos e de uma linhagem que costuma incluir mais escritores argentinos (Arlt, Bioy, Piglia) do que brasileiros. A estratégia narrativa de tomar como ponto de partida a história e a memória alheias também evoca a forma borgeana da reescritura. Entretanto, a ponte que o scriptor dos contos de Borges executa entre a cultura dos iletrados e a dos eruditos não aparece em Carvalho. Neste, a história popular não aparece, nem a voz do homem comum. O jogo de falsos discursos que articula a narrativa de Carvalho torna possível pôr na boca de uma figura como um sushiman uma frase que caberia a um crítico literário, sem fugir à verossimilhança. Da 
mesma maneira, o gosto reflexivo e filosófico das ficções de Borges parece substituído, no autor brasileiro, por um ensaísmo jornalístico e de reportagem diluído na narrativa. Entre os autores contemporâneos, seria possível aproximar Carvalho, talvez pelo exercício de investigação documental, talvez pelos movimentos de viagem, de autores como Sebald, sabendo de antemão, todavia, que a máquina de rememoração que move a narrativa do escritor alemão é impossível em personagens que atuam como máscaras.

Há quem diga que a literatura de Carvalho é elitista, e muitas vezes escorrega para o superficialismo. De fato, ela pressupõe do leitor uma carga de informação e leitura e uma disposição para a investigação letrada e jornalística; também não dá chance para a construção de personagens que estejam fora desse mundo, fora dessa linguagem. É curioso como a leitura dos livros de Carvalho, de enredo tão complexo, provoca muitas vezes a sensação de esquecimento própria dos mundos excessivos. Os fios das histórias não resistem na memória, como também não resiste a memória dos personagens sem identidade. Entretanto, eis aí a questão. Ler Carvalho esperando o conforto de um reconhecimento, de uma intimidade compartilhada, de um parentesco ou uma família, algo que vasculhe e revele um desejo de se sentir em casa, buscar ainda nessa literatura a voz vigorosa de um indivíduo ou de uma figura popular (como desejavam, e se frustraram, segundo relatou o próprio Bernardo Carvalho certa vez, os nômades com quem conviveu na Mongólia para escrever o romance homônimo), é lê-lo a partir de convenções que não cabem em sua literatura. O prazer desses romances deve ser outro, talvez o do descompromisso com a verdade, o da imaginação radical, o mesmo prazer que a alguns proporciona a montagem de um sofisticado quebra-cabeças, mas agora com peças que, no final, são mais curiosas, porque não pertencem ao livro que está ali. 